\title{
Merging and Simplification of Labour Legislation through Codes: The Process Needs to Draw Insights through Qualitative Research Initiatives
}

Dr Indrajit Goswami ${ }^{+*}$ and Prof. Caral D’Cunha ${ }^{\top}$

\section{Abstract}

It may be difficult for the small and medium enterprises to deal with a large number of labour legislation but it is not adequately known as to what extent that affects large organisations, including MNCs. The multiplicity of labour legislation and overlapping of different legal provisions may create bottlenecks for both, the smooth industrial operations and harmonious relationship between the employers and employees. Also, it is predictable that merging of multiple labour laws into four codes may improve operational efficiency and relations in the industries across sectors. However, how far such codification will correlate with issues like jobless growth, employment generation, reviving manufacturing, contract labour conundrum, the creation of more salaried jobs etc.? There is very little empirical evidence or acceptable rationale to answer this question. Every major problem or issue in society and industry may not be resolved only through political and judiciary interventions. It requires insights through multidisciplinary studies, not primarily through analytics but with the help of grounded theory, ethnography, phenomenological study etc. If our efforts, especially initiatives for the codification of laws, fail to make the entire process inclusive, we may later experience disintegrative and adverse outcomes. This article aims to initiate a thought process to understand if qualitative research can substantially contribute to the process.

Keywords: Central Labour Legislation, State Labour Legislation, Multiple and Overlapping Legal Provisions, Codification of Laws, 4-codes, Qualitative Research, Grounded Theory, Ethnography, Phenomenological Study, India

\section{Introduction}

Recently the authors attended a convention on industrial relations with a focus on '4-codes: A roadmap for labour market reforms' jointly organised by Bombay Management Association, National HRD Network and TISS, Mumbai. The event was graced by presence and contributions from senior executives across corporate organisations, senior trade union leaders, academicians, activists, researchers and students. The theme and focus of the convention were on '4-Codes'. However, the deliberations, discussions and debates predominantly were on managing industrial relations between management representatives and trade unions. As academicians and researchers, the authors were keen to know about the mechanism of codification of existing labour laws to merge and simplify. Back home, the authors started searching the appropriate literature to explore and trace the origin of the thought process favouring codes in the domain. The present article may not create any impact on the already initiated process and the bills pending in Lok Sabha to be passed as Acts. However, it is expected that the article shall initiate a momentum among the academicians, researchers, practising managers and other stakeholders to think critically and create a greater social consensus to keep the issue live and relevant for further revision, modification and development of 'codes' through the process

\footnotetext{
${ }^{\dagger}$ Professor-HR and Associate Dean-Research, N.L. Dalmia Institute of Management Studies and Research, Mira Road (East), Mumbai-401104. E-mail: indrajit.goswami@nldalmia.edu.in

${ }^{*}$ Corresponding Author

${ }^{\top}$ Assistant Professor-HR, N.L. Dalmia Institute of Management Studies and Research, Mira Road (East), Mumbai401104. E-mail: caral.dcunha@nldalmia.edu.in

(C) 2018 Goswami and D'Cunha. This is an Open Access article distributed under the terms of the Creative Commons Attribution License (http://creativecommons.org/licenses/by/2.0), which permits unrestricted use, distribution, and reproduction in any medium, provided the original work is properly cited.
} 
of consolidation. If the issue of 'codes' has the potential to bring back 'hire and fire' rule at the hands of employers, it is equally relevant to undertake continuous critical reviews to evaluate the impact of codes on the life of contract labourers, their families and their overall life situations.

The conceptualisation of this article has been based on the authors' learning through the conference presentations and discussions, followed by a substantial review of newspaper articles and understanding the philosophical assumptions behind different qualitative research methods. In the following sections, a sincere effort has been made to present and portray the existing narratives, theoretical concepts and different perspectives to understand the pros and cons of 'Codes' and 'Coding process'. It begins with a background discussion of the issue; following this, it discusses the four codes of the Union Minister of State for Labour, Government of India, which has been trying to find a road towards simplification of the labour laws. In the final section, we put forth a discussion on developing codes using qualitative research.

\section{The Backdrop}

A news item published in the Hindu (2015, October 15) has rightly pointed out that the basket of labour legislation in India reminds our colonial past, and a consequent obsession for that has brought in other institutions, mechanisms and critical procedures as reactive measures to settle disputes than building harmony between the 'managers' and the 'managed'. Even what we refer today as modern legislations in the domain are decades old. Our legislators perceived worth in multiple laws and their serial amendments than consolidation. As a result, there are 44 central labour legislations and more than a hundred state legislations (The Hindu, 2015, October 15). Apart from protecting the interests of the labourers and promising justice to them, the laws have been entrusted to protect the federal structure of the country too. The multiplicity, complexity and overlapping matters of those laws have created a gulf of trust between the industrial establishments, the elite executive class and the labourers. Even the narratives of the statute have emerged critical for common persons to understand and interpret provisions without any expert help. Also, it is perceived to be multiple tasks for employers to govern an effective and productive relationship between employer and employee through the basket of labour laws. Very recently, the central government has realised that this is equally embarrassing to the prospective investors, both from India and abroad.

Is the design of code inclusive and holistic? Hardly, there is any concrete evidence to establish undisputed faith and trust of common people on such coding mechanism or policy. It is fairly known that in 2002, the second Indian National Labour Commission proposed rationalisation of labour laws in India. However, initiatives had been visible only since 2017 .

\section{The Four Codes}

According to the Union Minister of State for Labour, Government of India, the four codes are (i) labour wages (ii) industrial relations, (iii) social security and welfare and (iv) safety and working conditions. Perhaps among these four codes, the consolidation and simplification of 'wage' appears to be comparatively challenging and critical because it attempts to merge four different labour laws, such as (i) the Payment of Wages Act, 1936, (ii) the Minimum Wages Act, 1949, (iii) the Payment of Bonus Act, 1965 and (iv) the Equal Remuneration Act, 1976 (Sharma, 2014). It may not be feasible to discuss narratives through provisions of all four legislation here, but one thing appears to be very simple that the 'wage code' merges all related terms, such as 'wages', 'salary', 'remuneration' and 'bonus' in to one single and universal term 'wages'. Therefore, one can argue as to how could the Central government plan to issue directions to the State governments in respect of wage fixation? It is a power exclusively vested with the respective States. The central government plays the role of a moral agent than showing appropriate empathy to the labour class by proposing the universal minimum monthly wage as '₹ Rs.18, 000'. The expert committee members might 
have done a lot of homework and data analysis to arrive at that amount. However, there is no adequate reference available to understand the changing social and cultural interpretations of the terms 'minimum wage', 'living wage' and 'fair wage.' How could one justify the merging of all terms into one? Are there any research evidence to establish that independently all those terms have lost relevance today? If law emerges through social, moral and ethical conscience, then it would be unfair to bring massive transformation in labour laws without revisiting its sources. Sometimes economic compulsions may dominate political decisions, however, any major decision in greater social interest must evolve through a larger social conscience. Otherwise, the process of codification may lose its validity and credibility. As in business, it is essential to ensure the 'quality of product and service', it is equally important to improve 'quality of life' of the employees, including contract labourers. The logic which justifies the increase of earnings of shareholders of a profitable venture, with the same logic the benefits must be proportionately distributed among the labourers. Perhaps the 'phenomena' such as 'investment of money' and 'investment of physical or intellectual labour' have been more instrumental as political constructs than social constructs. A perceptual gap between the two has been fabricated very strategically through a nexus of capitalist and political forces. While capitalists preferred to control 'money and market', political parties had chosen 'labour' as an instrument to manipulate democracy to achieve their goals. Consequently, the nexus has failed to establish any equitable relationship between 'money' and 'labour.' Rather the differences between the two factors of production continuously fuel politics in democracy. While in the first case the investor has every right to expect higher levels of returns but labourers' expectations have been constrained through 'codes' and 'convergence of laws'. Do the companies follow the equity principle while extending such benefits to both the shareholders and employees?
We can assume that $₹ 18,000$ as minimum wage may help the government to check rural to urban migration, but such income is inadequate to live a dissent family life in any city or urban area. The concept of minimum wage might have been relevant during the early stages of industrialisation (industry 1.0), when industries had to draw a large number of labour from rural areas for their operations. The governments then as guardian of public sector organisations had some moral (and legal) responsibility to fix wage to protect their interests. But in recent times, the 'protectionism' is neither appreciated in the globalised world nor is it practised by industry In the post-liberalised era, the competition among organisations is not merely restricted to products and services, but it has equally impacted the designing of 'pay structure', more specifically the 'variable-pay component' to attract and retain talents. Since governments are no more willing to run industries and so they shall leave it to market to decide the pay structure or at least it can play the advocacy role to promote the interests of the labour by raising the issues related to quality of life and fair and living wages, but not through showing political obsession for minimum wages. How long will 'Aam Aadmi' (common person) look towards constitutional safeguards and remain ignorant about their hidden potential to raise the bar of their life and strive for a fair and living wage? People should be encouraged to embrace positive values and the importance of 'dignity' and self-respect. They must be politically led for a better and deserving life, and they should never be manipulated to live their lives as parasites. To the best what governments can do is to remain watchful so that there is no exploitation of labourers and that can be done without being obsessive for prescribing a minimum wage. The other 'codes' are to be valued with due diligence so that all four codes together guarantee a graceful and quality life for the labourers. In 1990, the top 10 per cent of India's population earned around 34 per cent of the national income. By 2016, that jumped to 55 per cent (World Inequality Report, 2018). It happened because the upper-income groups have been benefited more through the 
economic reforms of the 1990s. If 'demographic dividend' has been considered and projected as one of the drivers of growth, then how the workforce could be deprived of getting an equitable share of overall industrial revenue regarding wage, bonus and other incentives? Together, there is a need to create a society where people be granted an equal and equitable distribution of income beyond any kind of discrimination and practice of protectionism.

\section{Job Security or Job Creation?}

Out of an estimated 125 million youth in the age group of 14-18, about 85 per cent live in rural India. A survey in 1641 villages of 24 states in India reveals that majority of the youth do not possess basic minimum skills and knowledge to get employment in the formal sector (Krishna, 2018). Their learning deficits either compel them to live a miserable life in a declining rural economy or push them to urban ward migration to find a living in the third sector. Another observation states that the unemployment rate in India is about 3.5 per cent and the majority of them fall in the age group of 15-24. The worrying fact is that most of the unemployed youth is the potential first-time worker and their percentage jumped from 10 per cent in 2014 to around 11 per cent in 2018 (Nanda, 2018). The existing scenario perhaps demands more comprehensive plans and actions, especially for youth in rural areas, so that they can effectively contribute to the development of the rural economy, including agriculture and agro-based industries. Hence, along with efforts to strengthen MSME sectors for employment generation/job creation, the governments must adequately provide policy support and financial assistance to create better education and employment opportunities in rural areas. While the urban job seekers look for jobs and career in the organised sectors, the majority of the youth in rural areas are failing to get sustainable employment and income opportunities in agriculture and agro-based industries. The most

\footnotetext{
${ }^{1}$ This is a perspective or assumption based on dialogues aired via news channels and newspapers. Also some of the trade union leaders attending the conference (where the authors too were present) shared the same perspectives.
}

recent union budget-2018 has pushed for the development of rural infrastructure, and that is expected to create millions of contract job opportunities for rural youth. It is fine that the governments are primarily concerned about job creation and not job security, but it requires a guarantee and assurance that there would be continuity of employment and income opportunities in the market. Perhaps, the debate is not on 'contract labour versus permanent labour' but between 'residual legal protection versus creating employment opportunities'. ${ }^{1}$ The government may enforce the law to favour the practice of contract labour through fixed-tenure employment. Already the central government has brought legal sanction for the practice in the textile sector in 2016 and now planning to extend the provision in other sectors too. Also, a proposal through the 'Industrial Employment (Standing Orders) Central (Amendment) Rules, 2018' promotes 'free labour movement' but reinstates the practice of 'hire and fire' policy (Nanda, 2018). The proposed law may empower employers not to renew employment contract with temporary or 'bodli' workers, but such liberty shall never violate the principles of humanity and justice, in case the contract workers have proved their worth and demanded higher pay/incentives. While the draft rules promise pay parity and statutory benefits to fixed-term contract workers, it gives freedom to employers to treat differently those who somehow survive jobs for consecutive three months and those who fail to do so. Why not a 15 days' notice be made mandatory even for those who fail to survive jobs for three months? An intimation well in advance to all before removal or retrenchment is something very fundamental, and discrimination on any form associated with it may not be well received by civil society.

\section{Employment Code versus Consolidation Code}

While the Central government is in the process of consolidation of labour laws into selected

\footnotetext{
${ }^{2}$ It is a term used in local/Hindi language signalling casual labour.
} 
codes, the government of Jammu \& Kashmir rolls the idea for employment code to enable workers, employers, trade unions, labour authorities and other users to get all information at one place (Gupta, 2018). Gupta (2018) is from NITI Aayog, Government of India and she argues in favour of employment code. May be it is right that we have complexities and multiplicity in labour laws due to the existence of varied industrial sectors and the Constitutional division of legislative powers between Centre and States. Also, Gupta (2018), being a lawyer herself argues that law shall contain the main provisions and rules can address the modalities or operational issues. According to her, it is better to have (i) a consolidated labour law covering all employees with a fewer exceptions, (ii) flexible and minimum standards for employment, (iii) provision for effective collective bargaining and (iv) reduced number of authorities and simple procedures.

It may be politically justified to have a vast and adapted Constitution to address the needs and issues of citizens in general, but not the 'labour codes.' The process of deriving such codes should evolve through a larger consensus and insights through scientific inquiry or research. The government shall consult with experts of respective fields, and shall also encourage and support research initiatives to understand the ground realities for such coding and its further implications. Otherwise, a politically manipulated and market dominated process can never create an inclusive and equitable system of governance, including law, policy or institution. Further, one needs to critically compare and evaluate the contemporary government initiatives from the perspectives of the World Bank's call for creating more salaried jobs (Mishra, 2018). However, it is not known whether the justification is given by the government behind the promotion of fixedterm contract labour for creating more employment opportunity, adequately addresses the concern of the World Bank? The draft Systematic Country Diagnostic (SCD) for India hardly provides any reference. The World Bank observes if India fails to overcome job deficit syndrome it may experience demographic curse instead of a demographic dividend. To achieve our desired goal, we need to create productive and regular jobs, and as World Bank suggests (Mishra, 2018), we have to regularise land reform through clearly defined property rights, installation of reliable land registry and predictable processes for investment and changes in land use. Even if we want to create more employment opportunities amidst slow pace industry growth rate, we need to develop a robust market information system to guide labour movement among trades and industries.

\section{The Codes: Natural or Artificial?}

It is apparent that employers in the organised sector find it embarrassing to comply with 44 central labour laws and over 100 state laws. How could the organised sector be so sensitive to when about 94 per cent of India's workforce belongs to the unorganised sector and remains deprived of its basic rights? It is argued here that merging of all labour laws is essential because independently the laws have lost relevance today. What exactly could be the point of embarrassment? The multiplicity of laws or the power struggle between the Centre and State governments? How do one can categorically argue that earlier or older legal provisions have become obsolete, even when such laws have been amended whenever needed? Are we not disputing with our own actions or decisions? If we feel that the changing characteristics of emerging industries demand a different set of legal provisions and more flexibility to deal with the labour market, then we must try to generate new codes to match both, the aspirations of the people and expectations of industries. But governments still believe that merging multiple laws into simple labour codes will serve the purpose. Maybe our intention is progressive, but the approach we adopt is regressive. We prefer to do hard work by engaging with cumbersome exercise but show apathy to embrace the changing perspectives of people and society. How should the codes evolve, through the recommendations of appointed committees or drawing insights from people's perspectives? Would it be fair enough to ignore the digitally enabled economy, and be myopic 
and address the conventional labour market? The traditional labour market based on the manufacturing and distribution of physical goods will no longer be adequate to meet the growing demand for jobs. Instead, it would be futuristic and relevant if we could focus on creating an ecosystem of manufacturing, agriculture, distribution of goods and services, and emerging technology-enabled operations and services. The multiplicity of laws may be a hurdle for employment generation, but a multipronged strategy is the need of the hour to generate maximum benefits for the aspiring youths in the fast-changing and disruptive business environment. It could be irrelevant if we rely on old patterns, definitions and legal provisions to measure and satisfy the ambitions of the youth. Instead, we need to engage with them through effective initiatives, such as dialogue, discourse, research interventions etc. to adequately map the millennial and their aspirations.

\section{Developing Codes through Qualitative Research}

While the government of India is moving towards simplification of labour laws for the ease of doing business, the corporate organisations do not show much interest for doing all round good for the employees (India Responsible Business Index, 2017). Chowdhry (2018) further observes that the companies mostly comply with the law, but they lack the broader interest to fight against inequality and extending employment opportunities to the marginal sections of the society. Such an apathy towards social inclusion, including in recruitment and selection, shall hardly create fair opportunities for the marginal sections through the promotion of contract-based employment. The findings of the third edition of the India Responsible Business Index (2017) indicate that the performance of corporate organisations in socially inclusive business is less admirable. Although most of the findings and insights are related to their CSR activities, yet

\footnotetext{
${ }^{3}$ There is very little research conducted so far in this area. Reading through Grounded Theory and understanding its
}

the Index (IRBF, 2017) has categorically highlighted the fate of contract employees.

The issues and concerns emerging in the sector are very sensitive, and so the political leaders, legal experts, policy makers, bureaucrats and other relevant stakeholders need to have a better empathetic understanding about the expectations and problems of the contract employees and a large number of potential young labourers awaiting employment opportunities in different sectors. The empirical studies and insights through analytics are important but not sufficient to develop empathetic understanding about them. It may require multiple qualitative research interventions with emerging methodologies, such as grounded theory (Strauss \& Corbin, 1990, 1998; Corbin \& Strauss, 2007; 2015), ethnography (Van Manen, 1988, 2011; Atkinson, 2015; Madison, 2005, 2011), phenomenological study (Natanson, 1973; Moustakas, 1994; Stewart \& Mickunas, 1990; Van Manen, 2014) and narrative research (Clandinin \& Connolly, 2000; Clandinin, 2013; Pinnegar \& Daynes, 2007) method.

The grounded theory ${ }^{3}$ may help us to understand the actual working conditions and relationship on the job through the experiences of the contract labourers, their hardships on the job, coping abilities, etc. An extensive study with this method may help us evolve a theory of contractual employment which would be realistic and conventional. It may help us to trace or locate different causal factors which directly or indirectly influence the performance and living of contract employees on the job. On the contrary, depending on our contexts, we may not require a theory but very specific descriptions about different types of occupational and social transactions among the contract employees and their transactions with their employers to understand if any culturesharing group exists at the job sites. Insights drawn from ethnography may lead us to identify the common issues which may later be codified through appropriate legal provisions to avoid

scope, was an inspiring input for us to suggest the approach here. 
further confusions and potential dilemmas in functional relationships. Similarly, through narrative and phenomenological study, we can capitalise the content and context of their job experiences and later combine both to retrieve the essence of their experiences. Such exercises shall definitely help us to develop empathetic understanding about job and life situations of the contract employees.

\section{Conclusion}

The government believes that the consolidation of labour laws followed by appropriate codification will ensure minimum wages, bonus, maternity benefits and welfare measures to the contract workers in small factories. It is evident that the existing laws contain varied definitions of employers, workers, wages, etc., and the move towards merging of such laws will lead to resolving the interpretation issues. The initiative by the government primarily aims to make employers comfortable in running businesses. There has been no doubt that the proposed labour codes will have positive impact on business. But, does it guarantee that codes will address the core humanitarian issues, including equality, justice, fair treatment and potential crises due to lack of consistent employment opportunities? Hardly there is any admirable evidence to establish that the related legal, political and judiciary processes have been adequately empathetic by understanding and incorporating the real-life experiences and expectations of the contract workers. We shall never be misled by the hyperactive and tall claims of artificial intelligence and big-data analytics in determining the destiny of industry and humanity. However, an inclination towards cognitive thinking and qualitative studies along with deep science may prove to be more holistic and sustainable.

\section{References}

Atkinson, P.A. (2015). For ethnography. Thousand Oaks, CA: Sage.

Chowdhry, Seema (2018, 26 February). Social inclusion is not priority for Indian businesses: Survey, Mint, Mumbai .
Clandinin, D.J. \& Connelly, F.M. (2000). Narrative inquiry: Experience and story in qualitative research. San Francisco, CA: JosseyBass.

Clandinin, D.J. (2013). Engaging in narrative inquiry. Walnut Creek, CA: Left Coast Press.

Corbin, J. \& Strauss, A. (2007). Basics of qualitative research: Techniques and procedures for developing grounded theory (3e). Thousand Oaks, CA: Sage.

Corbin, J. \& Strauss, A. (2015). Basics of qualitative research: Techniques and procedures for developing grounded theory (4e). Thousand Oaks, CA: Sage.

Gupta, A. (2018). A first step in labour law reform, Business Standard, Mumbai, Vol. XXII (121), January 30, 2018.

India Responsible Business Forum (IRBF) (2018). India Responsible Business Index-2017 (//responsiblebiz.org/.Accessed on 1-3-2018).

Krishna, A. (2018). The state of education in rural India, Mint, Mumbai, Vol.12 (23), January 26, 2018.

Madison, D.S. (2005). Critical ethnography: Methods, ethics and performance. Thousand Oaks, CA: Sage.

Madison, D.S. (2011). Critical ethnography: Methods, ethics and performance (2e). Thousand Oaks, CA: Sage.

Mishra, A.R. (2018). India needs to create more salaried jobs: World Bank, Mint, Mumbai, 14 February 2018, p.18.

Moustakas, C. (1994). Phenomenological research methods. Thousand Oaks, CA: Sage.

Nanda, P.K. (2018, 26 January). Government bats for contract labour to increase job count, Mint, Mumbai, Vol. 12 (23).

Natanson, M. (Ed.). (1973). Phenomenology and the social sciences. Evanston, IL: Northwestern University Press.

Pinnegar, S. \& Daynes, J.G. (2007). Locating narrative inquiry historically: Thematics in the turn to narrative. In D.J. Clandin (Ed.), 
Handbook of narrative inquiry: Mapping a methodology. Thousand Oaks, CA: Sage.

Stewart, D. \& Mickunas, A. (1990). Exploring phenomenology: A guide to the field and its literature (2e). Athens: Ohio University Press.

Strauss, A. \& Corbin, J. (1990). Basics of qualitative research: Grounded theory procedures and techniques. Newbury Park, CA: Sage.

Strauss, A. \& Corbin, J. (1998). Basics of qualitative research: Techniques and procedures for developing grounded theory (2e). Thousand Oaks, CA: Sage.

Van Manen, J. (1988). Tales of the field: On writing ethnography. Chicago, IL: University of Chicago Press.

Van Manen, J. (2011). Tales of the field: On writing ethnography (2e). Chicago, IL: University of Chicago Press.
Van Manen, M. (2014). Phenomenology of practice: Meaning-giving methods in phenomenological research and writing. Walnut Creek, CA: Left Coast Press.

Sharma, Yogima (2014, October 14). Unified act on cards to replace 44 labour laws for small units. Retrieved from https:// economictimes.indiatimes.com/news/economy /policy/unified-act-on-cards-to-replace-44labour-laws-for-small-units.

World Inequality Report (2018). Retrieved from https://wir2018.wid.world/files/download/wir2 018-full-report-english.pdf

44 labour laws to be amalgamated into 4 codes (2015, October 15). Retrieved from https://www.thehindu.com/news/national/oth er-states/44-labour-laws-to-be-amalgamatedinto-4-codes. 